there are many who will miss his friendly advice and help.

He was a deacon and member of the choir at St. Aubyn's Congregational Church at Upper Norwood. His first wife, daughter of the Rev. J. I. Keyes, died in 1937. Of this marriage there were three sons and two daughters. His second wife, by whom he had three children, is the daughter of Sir Hubert Llewellyn Smith. G. A. H. Butthe

\section{Prof. Arthur Rohn}

A YeAr ago mention was made in these pages of the first centenary of 'ETH', as it has come to be internationally known, namely, the Eidgenössische Technische Hochschule, Zurich, or the Swiss Federal Institute of Technology. Now we have to record the death on October 3 of the man who more than any other in his generation helped to give the Institute the position it holds as a centre of teaching and research in the field of technology in the widest sense of the term: Prof. Arthur Rohn, former president of the Institute's board and rector as well as a msmber of the professorial staff during eighteen years.

In the twenty-two years from 1926, when he was appointed head of the Institute, until 1948, when, greatly admired and respected as one of the country's élite, he gave his farewell address, Prof. Rohn had determined the policy and guided the development of the Institute in a way that earned him the gratitude of scholars, students and industrialists all over the world. His greatest achievement is the creation of more than two dozen specialized research centres in the form of institutes, which he helped to provide with sufficient grants, libraries, staff and special buildings. In addition to this, he persuaded the Swiss Government to create forty new pro. fessorial chairs in the field of pure and applied science. If the research institutes, for example, of aerodynamics, town and country planning, industrial accountancy, bear witness to his far-sighted vision, other innovations, like the new chairs for theoretical physics and mathematics, show his insistence on solid basic research in fundamentals.

Before he was called to the post of president of the Institute's Board, Prof. Rohn had held for nearly twenty years (1908-26) one of the most important chairs of civil engineering, that of structural engineering and bridge-building. Early and extensive experience in bridge-building in Switzerland and the Ruhr district had introduced him to this, his favourite field, in which he soon rose to be a master.

It was not only the eminence of the specialist nor the long experience as an academic teacher that enabled Arthur Rohn to exercise his brilliant leadership in higher professional education and industrial development, nor were these the only qualities that earned him the high respect - the veneration even that was felt for him in later years. He combined qualities that are not often found together in such fullness : breadth of vision with practical executive power and great firmness of will, a profound belief in the capacity of men to improve things, with a clear notion of what was possible, aristocratic aloofness with kindness and generosity and a sense of justice. It was this largeness of his mind and the impressive stature of his moral character that won him the admiration of his students and that inspired the Institute of which he was for so many years the head.

MAX WILDI

\section{A. Obruchev}

Vladimir afanasievich Obruchev, the premier geologist in Russia, died in Moscow on June 19, at the age of ninety-three. He was born on September 28 (Old Style), 1863, in Klepinino, Tver district, in the family of an army officer. He was educated in Vilna, and went to the St. Petersburg Mining Institute. After graduating as a mining engineer in 1886, he went to Central Asia where, following the lead of his teacher, Prof. I. V. Mushketov, he spent two years in the study of aeolian deposits. In 1888 he was attached to the Mining Department in Irkutsk.

'This was the beginning of Obruchev's work on the geology of Siberia, to which he devoted the rest of his life. At first he worked on the stratigraphy and tectonics of the Palæozoic and P're-Cambrian rocks of the Transbaikal and Lena region, and studied the geology of the gold fields. In 1892 he started on a series of travels to Central Asia, Dzungaria, Mongolia, China and various parts of Siberia. For a time he taught geology in Tomsk Polytechnical Institute (1901-12) and later in Taurida University at Simpheropol (1918-22) and in the newly founded Moscow Mining Academy (1922-28). In 1929 he was elected to the Academy of Sciences and during 1929-34 he was the director of the Geological Institute of the Academy. There are many other administrative and editorial posts which he filled at different times in his career.

Obruchev's publications are very numerous and they range over a wide field. His most important work deals with the geology of Siberia, on which he was a recognized authority. The three fundumental works on this subject aro: "I'he Geology of Siberia", in one volume (1926), published both in Russian and German ("Geologie von Siberien") ; "The Geology of Siberia", in three volumes (1935-38); and "The History of the Geological Fxplorations of Siberia", in five volumes (1931-42). The two best-known text-books written by Obruchev are: "Ore Deposits" and "Field Geology". His travel books include: "Central Asia, Northern China and Nan-Shan", "From Kyakhta to Kuldzha", "In the Mountains and Deserts of Central Asia", and "My Travels in Siberia". But even more popular were Obruchev's novels, all of them provided with a vivid geological setting, such as "The Land of Sannikov", "Goldseekers in the Desert", and "Plutonia".

Obruchev, in the eyes of his contemporaries, was not only a great geologist, a great traveller and a great writer ; he was also a man of striking personal charm, a remarkable organizer and a great character. $\mathrm{He}$ was very popular, especially with the young readers of his popular books and novels; it was said of him that he used to receive thousands of letters, and that none was left unanswered when an answer was asked for.

S. I. TهMKEIEFF

\section{Mr. D. L. Edwards}

WITH the death on September 23, after a brief illness, of Mr. D. L. Edwards, director of the Norman Lockyer Observatory of the University of Exeter for nearly twenty years, another link with Sir Norman Lockyer, eminent astronomer and founder and editor for many years of Nature, has been severed all too soon.

Donald Luther Edwards was born at Peterborough on January 11, 1894, into a family whose scientific 